\title{
Timeliness of Financial Reporting and Audit Committee Effectiveness: Evidence from UAE
}

\author{
Mohammed Ali Hussein Al-Muzaiqer, Maslina Ahmad and Fatima Abdul Hamid \\ Department of Accounting, Kulliyyah of Economics and Management Sciences, International \\ Islamic University Malaysia
}

\begin{abstract}
This study aims to examine the contemporary timeliness of financial reporting in the United Arab Emirates (UAE), and the impact of audit committee effectiveness on this timeliness. Timeliness of financial reporting in this study is measured by audit report lag (ARL), which is the number of days between the date of the financial year end and the date of the audit report. The data from listed companies on the UAE capital markets; Abu Dhabi Securities Exchange (ADX) and Dubai Financial Market (DFM), for three years from 2011 to 2013 resulted in 298 observations. The main statistical techniques of the study are means and multiple regressions. The findings show that generally all companies meet the submission deadlines imposed by the two UAE markets. Furthermore, ARL is influenced by audit committee size and profitability, while no evidence is found to support the effect of audit committee expertise, audit committee meetings and firm size on ARL.The results of the study show that only audit committee size has a significant influence in reducing ARL. This may be attributed to having minimal variation in the implementation of the Code of Corporate Governance (CCG), particularly audit committee attributes, in the UAE. The results suggest that the current governance by audit committees is adequate to ensure that the financial reports of companies in the UAE are timely. However, except for audit committee size, the other audit committee attributes are unable to further shorten ARL. The capital markets in the UAE and its CCG are relatively new. Hence, regulatory requirements may be less stringently implemented by companies in this country. Consequently, timely audited financial reports are demanded by local and international investors to make decisions and alleviate speculation. Thus, determining audit committee attributes that reduce ARL is beneficial to the UAE markets, the listed companies and investors.
\end{abstract}

Keywords: Audit report lag (ARL), Financial reporting timeliness, Audit committee, UAE

\section{INTRODUCTION}

Timeliness is one of the qualitative characteristics of accounting information. Timeliness implies making information available to decision-makers before it loses its ability to affect decisions (International Accounting Standards Board (IASB), 2010). Information also may lose its value if it is not available when it is needed. Therefore, the more promptly the information can be delivered to users of financial statements, the more relevant it is to the process of decision-making. Timely financial reporting is even more important in emerging markets. This is because financial reporting is considered the only reliable source of information for stakeholders in these economies. According to Afify (2009), issuing financial information in these markets has a longer time lag and the information made public is limited. Nelson and Shukeri (2011) also stated that, providing timely information is likely to be more important since the regulatory bodies in these countries are not as efficient as in developed economies.

Timely reporting is affected by audit timeliness due to the need for financial statements to be audited. In fact, according to Leventis et al. (2005), audit timeliness is the most influential factor in the timing of earnings announcements and the timeliness of financial statements. It has been reported by Bamber et al. (1993) that over 70 percent of companies do not issue their annual reports until the annual audit report date. Accordingly, any delay in the audit report could delay earnings announcements and issuance of corporate financial statements. Timeliness of the audit report is 
measured by ARL. ARL is well-defined in research literature as the number of days between an organization's fiscal year end and the date of audit report (Leventis et al., 2005; Harjoto et al., 2015).

The timeliness of financial reports is essential for effective investment decisions since they are an important reference for stakeholders. These days, international investors are attracted to global capital markets, and they rely on audited financial statements to make investment decisions. Timely financial reports are particularly crucial for the UAE as it is considered the centre of trade, and it has a greater number of multinational companies as compared to other Middle Eastern countries (Balakrishnan, 2008). Given the importance of the timeliness of financial reporting, recognising the determinants of financial reporting delay is considered an essential step to improve the quality of financial reporting. Therefore, it is imperative to investigate ARL and whether audit committee effectiveness could shorten ARL in order to produce timely financial statements in the context of the UAE.

Audit committees monitor effectiveness of internal controls, internal and external audit, and systems of risk management and the process of financial reporting. Thus, obviously an audit committee has a direct responsibility for the audit reporting process (Beasley et al., 2009). Prior studies by Afify (2009), Nelson and Shukeri (2011) and Ika and Ghazali (2012) provide evidence that an effective audit committee enhances financial reporting quality. It is believed that an audit committee, by its monitoring function, can advise and encourage the management to provide financial information on a timely basis (Song and Windram, 2004). Business risks are reduced when such procedures and mechanisms are in place. Subsequently, the work of external auditors is also reduced due to a lesser need to conduct extensive substantive testing and audit procedures (Nelson \& Shukeri, 2011). Therefore, an effective audit committee could enable a significant decrease in ARL.

The Code of Corporate Governance (CCG) in the UAE was established in October 2009 after the Minister of Economy issued the Ministerial Resolution No.518 of 2009. Since the CCG is only 8 years old; the effectiveness of the audit committee remains questionable, particularly in terms of decreasing ARL. Even though prior studies indicated that financial reporting quality would be enhanced when the audit committee is effective, studies linking audit committee effectiveness with ARL seems to be limited particularly in the context of the Gulf countries. Furthermore, the security markets in UAE; the Abu Dhabi Securities Exchange (ADX) and Dubai Financial Market (DFM) were only established 2000. Hence, the reporting requirements may not be as stringent as in established markets. Due to this, the ARL may be longer than that found in prior studies conducted in other countries and the audit committee may not be equally effective. Since no prior study has examined the issue of timeliness of financial reporting in the UAE, the current study seeks to fill the gap.

Based on the above, this study aims to measure the ARL of companies listed on the ADX and DFM. This study also analyses ARL based on industries in the UAE. Moreover, the current study attempts to examine the relationship between audit committee effectiveness and ARL in the UAE. The specific proxies for audit committee effectiveness are audit committee size, expertise of the audit committee members and frequency of audit committee meetings.

Research on audit committee effectiveness and its association with ARL within the UAE security markets will contribute to ARL literature and theory. As mentioned above, UAE markets are still emerging, and the CCG is considered relatively new, thus may be less effective. Consequently, the timeliness of financial reporting may be affected. As argued by Alkhatib and Marji (2012), the most important source and reference of accounting information available to external users is audited financial statements. Thus, regulators and researchers may be interested to know the average ARL in the UAE, and whether it is comparable to other countries. This can only be revealed after empirical evidence is attained. In addition, examining audit committee effectiveness in the UAE may help companies improve their corporate governance system if the results show that audit committee characteristics strongly affect ARL. On the other hand, regulators and companies in the UAE may have to consider other alternatives should corporate governance measures be ineffective. Therefore, 
findings from this study will be beneficial to regulators in determining whether imposed requirements regarding audit committee are actually able to reduce ARL.

This paper is organised as follows: the next section discusses prior literature; followed by a brief discussion on agency theory and hypotheses development. Then the research method is presented; next, the results of the study are discussed. Finally, the conclusion includes a discussion on the implications of the research in the last section

\section{CORPORATE GOVERNANCE IN THE UAE}

The UAE started dealing in securities in the early 1960s when several companies were incorporated in the country. At that time, securities were traded through brokerage or specialised non-licensed firms. However, as there were no securities markets, there was no proper regulation or monitoring of these companies. As a result, there was an urgent need to regulate the stock market to ensure the integrity of transactions and to protect investors. For this purpose, Federal Law No. 4 was enacted in 2000. This law gazetted the establishment of the Securities and Commodities Authority (SCA) of the UAE. Consequently, ADX and DFM were established in the same year.

The ADX and DFM serve the interests of the national economy by providing an opportunity and a mechanism to invest funds and savings in securities. These exchanges also ensure the accuracy and safety of transactions, promote the interaction of the forces of supply and demand to protect investors, set prices, and to support the foundations of appropriate handling of securities. They also strengthen control over trading in securities to ensure the safety of actions and procedures, and to create investment awareness to make sure that savings are channelled to productive sectors. Both ADX and DFM are regulated and licensed by the SCA. The following table shows the main requirements of listed companies in ADX and DFM.

Table 1: Requirements of Listed Companies in ADX and DFM

\begin{tabular}{|c|c|c|}
\hline & DFM & ADX \\
\hline 1 & $\begin{array}{l}\text { The company must be registered at the } \\
\text { Ministry of Economy and Planning }\end{array}$ & $\begin{array}{l}\text { The company issuing the securities should } \\
\text { be fully compliant with the provisions of } \\
\text { Federal Law No- } 8 \text { of } 1984 \text { Regarding } \\
\text { Commercial Companies and amendments } \\
\text { thereto. }\end{array}$ \\
\hline 2 & $\begin{array}{l}\text { The paid up capital should not be less than } \\
35 \text { percent of Shareholders' Equity, or not } \\
\text { less than AED } 25 \text { million, whichever is } \\
\text { higher. }\end{array}$ & $\begin{array}{l}\text { The paid up capital may not be less than } 50 \\
\text { percent of the stockholders' equity, which } \\
\text { may not be less than AED } 20 \text { million. }\end{array}$ \\
\hline 3 & $\begin{array}{l}\text { The company has to prove that it holds an } \\
\text { ordinary general meeting at least once a } \\
\text { year. }\end{array}$ & $\begin{array}{l}\text { The company has to prove that it holds an } \\
\text { ordinary general meeting at least once a } \\
\text { year. }\end{array}$ \\
\hline 4 & $\begin{array}{l}\text { The company should undertake to publish } \\
\text { financial accounts in the daily UAE media } \\
\text { before its stocks are traded in the market. }\end{array}$ & $\begin{array}{l}\text { The company should publish its financial } \\
\text { results in the daily media before its shares } \\
\text { traded in the market. }\end{array}$ \\
\hline 5 & $\begin{array}{l}\text { The company has to provide and publish } \\
\text { audited reports within } 120 \text { days of the end of } \\
\text { the financial year. The company's financial } \\
\text { statements should contain the interim } \\
\text { financial statements. }\end{array}$ & $\begin{array}{l}\text { Listed companies are committed to provide } \\
\text { the market with annual reports, within } 90 \\
\text { days of the end of the financial year and } \\
\text { quarterly statements within } 30 \text { days of the } \\
\text { end of the quarter. }\end{array}$ \\
\hline 6 & $\begin{array}{l}\text { The financial statements of the company } \\
\text { should contain the annual report for the last } \\
\text { two financial years prior to the submitting of } \\
\text { the listing application attached by the } \\
\text { board's report and a report from the auditor } \\
\text { of the company. }\end{array}$ & - \\
\hline
\end{tabular}

ADX (2015) and DFM (2016) 
Subsequent to the CCG being issued in 2009, listed companies in the UAE were required to comply with the new code by 30 April 2010. One of the requirements of this newly-established CCG is that the board of directors of companies listed on ADX and DFM must establish an audit committee. According to the code, the committee should comprise at least three non-executive directors, and the majority of them must be independent, including the head of the committee. The code also requires the committee to have at least one financial expert, and to meet four times during the financial year. The duties of the committee include, for example, reviewing the accounting policies and financial statements of the company, reviewing risk management systems, internal control and financial control, and overseeing the independence of the external auditor.

\section{AGENCY THEORY AND HYPOTHESES DEVELOPMENT}

Agency relationship is defined as a contract when one or more principals appoint another person - the agent - to perform services on their behalf. In order to do so, the agent needs to be delegated some decision-making authority (Jensen and Meckling, 1976). Agency theory proposes that, owing to the division of ownership and company management, shareholders necessitate safeguards because the management (or its agent) may have their own priorities which are different from the principals' objectives and goals. Consequently, the agent may not act on behalf of the principal (Fama, 1980).

According to Madaschi (2010), three types of agency problems affect the interests and the interaction of the subjects related to the firms: (1) agency problem type 1 between shareholders and management, (2) agency problem type 2 between majority and minority shareholders, and (3) agency problem type 3 between shareholders and stakeholders. It should be noted that the primary conflict of interests arises between shareholders (principals) and managers (agents) (Jensen \& Meckling, 1976).

Agency theory usually focuses on how to mitigate agency problems - such as asymmetric information - that arise from agency conflicts. To monitor these problems, both the agent as well as the principal need to increase control mechanisms and information systems to diminish information asymmetry (Jensen \& Meckling, 1976). One of the mechanisms proposed by agency theory to address these agency conflicts is by hiring an independent external auditor. This mechanism enables the company to produce high-quality information that helps the principal to monitor the agent and reduce information asymmetry, thus diminishing agency problems (Kent et al., 2010). The audit committee is responsible for proposing the external auditor and overseeing the audit function that takes place in the company. Thus, the audit committee plays a key role in possibly reducing agency conflicts. However, generally auditors, and thus the audit committee tend to focus on mitigating agency problem type 1 and may be less effective in resolving the other types of agency problems.

According to Carcello et al. (2006), an agency perspective suggests that an effective and efficient audit committee can achieve its supervisory role when it is independent of the management, has sufficient directors, has members who have financial expertise, and holds more frequent meetings. Therefore, an effective audit committee provides some reassurance that the managers will act in the best interests of the shareholders, especially in financial reporting and managerial performance (Nelson \& Shukeri, 2011). Thus, client companies with stronger audit committees are evaluated as having lower business risks. The external auditors are also able to place more reliance on the client's internal controls, hence decrease the need of extensive substantive testing (Sharma et al., 2009). In summary, an effective audit committee reduces auditors' work, subsequently reducing ARL.

\section{Audit committee size}

The role of the audit committee necessitates adequate resources to ensure its efficient performance. One of these resources is its sufficient size. A larger audit committee, with sufficient resources, can address issues faced by the company more effectively (Nelson \& Shukeri 2011). This could reduce agency problems in a timelier manner. Thus, it is expected that a large number of audit committee members, through the diversity of their knowledge, can enable external auditors to complete their work earlier, thus reduce ARL. Prior studies, such as Saleh et al. (2007), Pucheta-Martínez and 
Fuentes (2007), Goh (2009), and Naimi et al. (2010) provide evidence that a larger audit committee is more effective. These studies confirm that a larger audit committee is negatively related with qualified audit opinion, more likely to repair material weaknesses in a timely manner, and maximises the quality of oversight. These findings indicate that a larger audit committee is more effective. Extending from these findings, a larger audit committee is better able to monitor the audit process, provide advice to resolve problems faster and ensure that internal auditors perform their roles. Subsequently, external auditors may face fewer problems during their audit. This would enable them to perform their audit faster, hence reduce ARL. Based on the above discussion and referring to the agency theory, the following hypothesis is developed:

$\mathrm{H}_{1}$ : There is a negative relationship between audit committee size and ARL.

\section{Audit committee expertise}

Reviewing financial reports, the audit process, and internal controls are among the substantial duties of an audit committee. Thus, members of an audit committee should have sound knowledge of finance and accounting. Many definitions of financial expertise are used in prior studies. For example, Mangena and Pike (2005) define a financial expert as a certified financial analyst (CFA), a certified public accountant (CPA), or someone who has finance or accounting experience. Abbott et al. (2004), on the other hand, use a broader definition. They view an investment banker, a chief financial officer (CFO), a CPA, a controller, a venture capitalist, or someone who has held a senior management position with financial responsibilities, as a financial expert. The definition by Mangena and Pike (2005) is used in this study.

Agency theory dictates that audit committee members with financial expertise are better able to monitor internal controls and preparation of financial reports. Subsequently, occurrence of mistakes and errors are minimised, which reduces audit work and audit time. Consequently, ARL is minimised. Several studies provide evidence that a committee that possesses at least one financial expert is more effective (e.g., Abbott et al., 2004; Zhang et al., 2007; Ika, 2011). They confirm that having financial experts could improve financial reporting quality, diminish earnings management, ensure accruals quality, and reduce internal control problems. In contrast, Apadore and Noor (2013) found that committee expertise does not play a crucial role in reducing ARL.

Nevertheless, based on the above, most of the literature supports the idea that the financial expert would enhance the effectiveness of the audit committee. The findings from some studies above suggest that having such a committee member would reduce internal control and financial reporting problems. If these issues are monitored effectively and resolved, then there would be fewer problems for external auditor. Hence, the auditors can perform their audit smoothly without any or only minor defaults. Consequently, the audit process will be faster and the ARL will be shorter. Referring to the above, the following hypothesis is developed.

$\mathrm{H}_{2}$ : There is a negative relationship between audit committee expertise and ARL.

\section{Frequency of audit committee}

The frequency with which an audit committee meets reflects how active it is. The number of meetings held during a year shows the committee's extent of observing the quality of financial reporting (Bedard et al., 2004). Audit committees in companies listed in ADX and DFM are required to meet four times during the financial year. They should submit a report on committee activities to the board of directors periodically at least once every 3 months. It can be said that the shorter the time between meetings, the earlier the problems are identified and resolved. Hence, the auditors are more likely to complete their work and produce audit reports in a timely manner. Several prior studies offer insights into the importance of holding many meetings. Beasley et al. (2000) found that frauds were committed by firms that had only one meeting per year, while firms with two or more meetings per year did not commit fraud. Xie et al. (2003) and Saleh et al. (2007) show that earnings management is 
negatively associated with audit committee meetings. Abbott et al. (2004) report that companies with at least four meetings a year are less likely to have prior period financial restatement. In the same context, it is found that overall audit quality is improved and audit risk minimised by holding frequent meetings (Stewart and Munro, 2007). Moreover, Ika and Mohd Ghazali (2012) provide evidence that the number of audit committee meetings is negatively related with ARL.

Based on the above studies, it is evident that audit committees that holding more meetings during the year is considered more effective and efficient, and have greater ability to resolve problems. Specifically in relation to ARL, the auditor would have to report to the audit committee during the process of their audit. Should there be any problems to be resolved or activities to be approved, it would be faster if the audit committee meetings were held more frequently. Having more frequent meetings is in line with agency theory, which proposes increased monitoring. Thus, the audit process is not hindered by delay and the ARL will be reduced. Therefore, the following hypothesis is developed:

$\mathrm{H}_{3}$ : There is a negative relationship between the frequency of audit committee meetings and ARL

\section{RESEARCH METHOD}

Secondary data was gathered from the annual reports of listed companies on the two UAE markets. The annual reports were attained from the ADX and DFM websites. The population of listed companies on the ADX and DFM markets was 130, 123 and 120 for 2011, 2012, and 2013, respectively, totalling 298 observations. As shown in Table 2, all banks had to be removed from the sample because they did not issue corporate governance (CG) reports, thus audit committee data were unavailable. Then, companies with unavailable annual reports and companies with missing audit committee data had to be excluded. Therefore, the final sample was 62 companies for 2011,52 for 2012, and 35 for 2013. This gives a total of 149 firm-years, 89 and 60 from ADX and DFM, respectively.

Table 2: Population of Listed Companies and Final Sample

\begin{tabular}{lcccc}
\hline Number of companies & 2011 & 2012 & 2013 & Total \\
\hline Population of ADX & 67 & 66 & 65 & 198 \\
Population of DFM & 63 & 57 & 55 & 175 \\
Total Population & 130 & 123 & 120 & 373 \\
Excluded: & & & & \\
Banks & $(23)$ & $(23)$ & $(23)$ & $(69)$ \\
Companies with unavailable financial statements & $(17)$ & $(22)$ & $(21)$ & $(60)$ \\
Companies with missing audit committee data & $(28)$ & $(26)$ & $(41)$ & $(95)$ \\
\hline Final sample & 62 & 52 & 35 & 149 \\
\hline
\end{tabular}

The study used measure of central tendency, specifically means to determine the level of ARL in the UAE markets. Then, multiple regression analysis was used to test audit committee effectiveness on ARL. Audit committee characteristics are the independent variables and ARL is the dependent variable. All measures are consistent with prior studies (Afify, 2009; Che-Ahmad \& Abidin, 2008; Mohamad-Nor et al., 2010). The ARL model for this study is as follows:

$\mathrm{ARL}=\beta_{0}+\beta_{1}(\mathrm{ACS})+\beta_{2}(\mathrm{ACE})+\beta_{3}(\mathrm{ACM})+\beta_{4}(\mathrm{FS})+\beta_{5}(\mathrm{PRO})+\beta_{6}(\mathrm{MKT})+\beta_{7} \mathrm{Y} 2011+\beta_{8}$ $(\mathrm{Y} 2012)+\varepsilon$

Where $\beta_{0}$ refers to the constant coefficient whereas other betas are coefficients for the explanatory variables. The independent variables are audit committee size (ACS), audit committee expertise (ACE) and frequency of audit committee meetings (ACM). The control variables are firm size (FS) and profitability (PRO). Then, to complete the model, dummy variables were included to differentiate between the two markets (MKT) and to distinguish between the years (Y2011 and Y2012). $\varepsilon$ refers to the error term that describes the residual value which cannot be explained by the model. The measurement of each individual variable is shown in Table 3. 
Table 3: Summary of Measures of Dependent and Independent Variables

\begin{tabular}{|c|c|c|c|c|c|}
\hline Variables Name & $\begin{array}{l}\text { Variable } \\
\text { Code }\end{array}$ & Measurement & $\begin{array}{l}\text { Requirements in the } \\
\text { UAE }\end{array}$ & $\begin{array}{l}\text { Exp. } \\
\text { Sign }\end{array}$ & Prior Studies \\
\hline $\begin{array}{l}\text { Audit report } \\
\text { Lag }\end{array}$ & ARL & $\begin{array}{l}\text { The number of days } \\
\text { between the date of the } \\
\text { auditor's report and the } \\
\text { date of financial year- } \\
\text { end }\end{array}$ & $\begin{array}{l}90 \text { days in ADX and } \\
120 \text { days in DFM }\end{array}$ & N/A & $\begin{array}{l}\text { Carslaw and } \\
\text { Kaplan(1991) } \\
\text { and Bamber et al. } \\
(1993)\end{array}$ \\
\hline $\begin{array}{l}\text { Audit } \\
\text { Committee Size }\end{array}$ & ACS & $\begin{array}{l}\text { The number of directors } \\
\text { in the audit committee }\end{array}$ & $\begin{array}{l}\text { At least three non- } \\
\text { executive directors }\end{array}$ & - & $\begin{array}{l}\text { Goh (2009), } \\
\text { Nelson and } \\
\text { Shukeri (2011) }\end{array}$ \\
\hline $\begin{array}{l}\text { Audit } \\
\text { Committee } \\
\text { Expertise }\end{array}$ & $\mathrm{ACE}$ & $\begin{array}{l}\text { The proportion of audit } \\
\text { committee members with } \\
\text { accounting or finance } \\
\text { expertise }\end{array}$ & $\begin{array}{l}\text { At least one audit } \\
\text { committee member } \\
\text { should be a financial } \\
\text { expert }\end{array}$ & - & $\begin{array}{l}\text { Mangena and } \\
\text { Pike (2005), Ika } \\
(2011)\end{array}$ \\
\hline $\begin{array}{l}\text { Audit } \\
\text { Committee } \\
\text { Meetings }\end{array}$ & $\mathrm{ACM}$ & $\begin{array}{l}\text { The number of meetings } \\
\text { held during the year }\end{array}$ & $\begin{array}{l}\text { At least once every } \\
\text { three months }\end{array}$ & - & $\begin{array}{l}\text { Goh (2009), } \\
\text { Nelson and } \\
\text { Shukeri (2011) }\end{array}$ \\
\hline
\end{tabular}

\section{RESULTS AND DISCUSSION}

\section{Descriptive statistics}

Table 4 shows the mean ARL of all sampled companies listed on the two stock exchanges (ADX and DFM) in the UAE for 2011-2013. The table relates to the population of 298 companies that issued financial statements (113 companies for 2011, 110 companies for 2012, and 75 companies for 2013) to measure ARL. The table also shows that, overall ARL decreased from 2011 to 2013, from about 60 days to 51 days. Similar decreasing trends can also be observed based on separate market analysis, in which the mean ARL for ADX companies reduced from 58 days to 56 days from 2011 to 2012. A much better mean ARL performance can be seen for companies listed on DFM as it reduced from 62 days to 40 days from 2011 to 2013.

Table 4 shows that the banking sector has the shortest ARL amongst the listed companies. The average ARL of banks was about 39 days in 2011, which improved to 34 days in 2012, then 32 days in 2013. The ARL of the other industrial sectors were mostly in the range of 55 to 75 days. Only the 'Real Estate' sector and 'Transportations' sector had ARL of 49 and 48 days, respectively in 2013. In contrast, the 'Telecom' sector's ARL increased to 84 days in 2013. Three sectors showed a clear declining trend of ARL from 2011 to 2013. They are: consumer staples, real estate and transportation. The other sectors show a fluctuating ARL between the three years. Nevertheless, 'Insurance and services' sector and 'Industrial' sector have the lowest ARL in 2013 compared to previous years. Their ARL was 57 days and 59 days, respectively. On the other hand, 'Energy' sector and 'Telecom' sector have the highest ARL in 2013 compared to the previous two years. Their ARL was 79 days and 84 days, respectively. 
Table 4: Mean Audit Report Lag (ARL) of Listed Companies on ADX and DFM

\begin{tabular}{lccc}
\hline & 2011 (Days) & 2012 (Days) & 2013 (Days) \\
\hline Number of Companies & 113 & 110 & 75 \\
ARL (both markets) & $\mathbf{5 9 . 8 1}$ & $\mathbf{5 6 . 9 5}$ & $\mathbf{5 1 . 4 0}$ \\
ARL (ADX) & 58.48 & 57.33 & 55.77 \\
ARL (DFM) & 61.50 & 56.47 & 39.94 \\
ARL by Sector: & & & \\
Banks & 38.91 & 34.05 & 32.11 \\
Insurance and service & 61.78 & 62.30 & 56.77 \\
Consumer Staples & 74.25 & 55.63 & 55.33 \\
Energy & 73.50 & 71.50 & 78.50 \\
Industrial & 66.19 & 69.60 & 59.08 \\
Real Estate & 56.80 & 56.00 & 48.80 \\
Telecom & 71.60 & 71.00 & 84.00 \\
Transportation & 68.00 & 64.67 & \\
\hline
\end{tabular}

Table 5 provides descriptive analysis of the variables to measure audit committee effectiveness. Table 5 relates only to the sample of 149 companies that issued CG report to measure audit committee effectiveness. This explains the difference in the mean of ARL between Table 4 and Table 5. Based on a sample of 149 companies listed on ADX and DFM from 2011 to 2013, the table shows that the mean ARL is 60.41 days. This means that external auditors of these listed companies take an average of 60 days to complete their audit work, with a minimum of 8 days and a maximum of 91 days. This also means that most of the UAE listed companies in the sample meet the requirement of issuing financial statements within the specified time frame. As mentioned before, ADX requires listed companies to issue their financial statements within 90 days after the end of the financial year, whereas DFM requires listed companies to publish their financial statements within 120 days after the end of the financial year. Since the company, which had the ARL of 91 days was listed on the ADX market, it exceeded the 90 -day deadline set by the market by one day.

These results also provide evidence that the ARL of companies in the UAE, on average, is shorter than that of other developing countries. For example, Abdullah (2007) found that from 1998 to 2000, listed companies on Bursa Malaysia took an average of 105 days to announce their audited financial reports. Using a sample of 85 listed companies in 2007, Afify (2009) reports that auditors need an average of 67 days to complete audit work in Egypt. Ika and Ghazali (2012) studied ARL in the Indonesian stock exchange for 2008. They reported that it takes the auditors 98 days to publish audited financial reports. However, it is essential to note that these results are based on 2011-2013 data of companies that issued their annual reports on ADX and DFM websites.

Regarding audit committee effectiveness, Table 5 shows that the mean audit committee size (ACS) of companies in UAE financial markets is 3.3, with a minimum and maximum of 3 and 6 directors, respectively. This suggests that UAE listed companies have audit committees with no fewer than three members on average, which meets the requirements of the CCG. The mean audit committee 
expertise (ACE) is 0.26 , with a minimum and maximum of 0 and 1 respectively. This implies that on an average, about 26 percent of audit committee members have accounting or finance knowledge. The results also show that there are companies without financial expertise on their audit committee. Finally, the frequency of audit committee meetings (ACM) on average is about four meetings per year. This finding suggests that UAE listed companies have audit committees that meet four times a year, in compliance with the CCG. However, there are companies with no ACM at all, even though all companies have audit committees. On the other hand, a company had 11 meetings, which indicates that the audit committee of this company had a meeting nearly every month. In regard to the control variables in Table 5, starting with firm size (FS), the mean of company size was found to be AED 4.6 billion with minimum and maximum size being AED 56 million and AED 72.9 billion, respectively. On the subject of company profitability (PRO), the mean profitability of UAE listed companies is 0.02 , ranging from -0.20 losses to 0.26 profits. This suggests that UAE listed companies by using the same measure (return on assets) were less profitable compared to Egyptian companies that, on average, were profitable at 0.1 return on total assets (Afify, 2009).

Table 5: Descriptive Analysis

\begin{tabular}{|c|c|c|c|c|c|c|}
\hline & Minimum & Maximum & Median & Mean & Skewness & Kurtosis \\
\hline ARL & 8 & 91 & 59 & 60.41 & 60.41 & 60.41 \\
\hline ACS & 3 & 6 & 3 & 3.30 & 3.30 & 3.30 \\
\hline $\mathrm{ACE}$ & 0 & 1 & 0.33 & 0.26 & 0.26 & 0.26 \\
\hline $\mathrm{ACM}$ & 0 & 11 & 4 & 4.36 & 4.36 & 4.36 \\
\hline FS & $56,136,474$ & $72,891,642,000$ & $1,431,830,000$ & $4,614,947,242$ & 0.30 & -0.31 \\
\hline $\mathrm{PRO}$ & -0.20 & 0.26 & 0.03 & 0.02 & -0.57 & 2.60 \\
\hline
\end{tabular}

\section{Correlation results}

Table 6 shows the relationship between ARL and other variables. From the table, it appears that ARL has a negative and significant relationship with audit committee size (ACS) at 1 percent. Other variables - including audit committee expertise (ACE) and audit committee meetings (ACM) appear to have no significant correlation with ARL. Table 8 provides evidence that the highest correlation is between Y2011 and Y2012 at - 0.618. This indicates the absence of the multicollinearity problem since the correlation between the variables is less than \pm 0.90 (Pallant, 2001).

Table 6: Pearson Correlations

\begin{tabular}{lccccccccc}
\hline Coeff & ARL & ACS & ACE & ACM & FS & PRO & MKT & Y2011 & Y2012 \\
\hline ARL & 1 & $-0.211^{* *}$ & 0.095 & -0.087 & -0.028 & -0.353 & 0.014 & 0.106 & -0.093 \\
ACS & & 1 & -0.091 & 0.075 & 0.045 & 0.073 & -0.135 & 0.018 & -0.009 \\
ACE & & & 1 & -0.125 & 0.005 & -0.006 & -0.025 & -0.144 & 0.139 \\
ACM & & & & 1 & 0.361 & -0.076 & -0.108 & -0.024 & -0.020 \\
FS & & & & & 1 & 0.121 & -0.155 & -0.050 & -0.037 \\
PRO & & & & & & 1 & 0.040 & -0.034 & 0.028 \\
MKT & & & & & & & 1 & 0.055 & 0.055 \\
Y2011 & & & & & & & & 1 & $-0.618^{* *}$ \\
Y2012 & & & & & & & & & 1
\end{tabular}

$A C S=$ Audit Committee Size, ACE = Audit Committee Expertise, ACM=Audit Committee Meetings, $F S=$ Firm Size, $P R O=$ Profitability, $M K T=$ Market $(1=A D X, 0=D F M), Y 2011=(1=$ Year 2011, $0=$ Otherwise), Y2012= $(1=$ Year 2012, $0=$ Otherwise $)$

${ }^{*}$ Significant at 0.05 level $\quad{ }^{* *}$ Significant at 0.01 level 


\section{Multiple regression results}

The multiple regression results are presented in Table 7. The findings showed that audit committee size (ACS) has a significant negative relationship with ARL. This finding provides evidence that UAE listed companies with large audit committees have faster publishing of audited financial reports. This finding is consistent with Nelson and Shukeri (2011), who found significant relationship between audit committee size and ARL using Malaysian setting. Thus, the findings support the first hypothesis of the study $\left(\mathrm{H}_{1}\right)$.

On the other hand, Table 7 revealed that the impact of audit committee expertise (ACE) on ARL is negative but not significant. In referring back to Table 5, the majority of the companies in the sample have at least one member who possesses accounting experience and these companies hold audit committee meetings at least four times a year. These findings seem to indicate that the listed companies in the UAE are complying with the regulatory requirements. Consequently, the results show that there is no significant effect of ACE on ARL possibly due to there being little variation on ACE between the companies. Similarly, the result for audit committee meeting is not significant, however the t-value is positive and inconsistent with the study's hypothesis. A positive direction suggests ARL increases as the number of audit committee meeting increases; nevertheless, the coefficient is insignificant. According to Al-Ajmi (2008), the lack of significant results may be explained by minimal variation, small sample size and a lack of statistical power. Thus, the findings do not support $\mathrm{H}_{2}$ and $\mathrm{H}_{3}$.

In relation to the control variables, the results indicate that profitability (PRO) has a negative significant impact on ARL at 1 percent significance level. As expected, this indicates that more profitable companies issue their audited financial reports faster. This finding is consistent with the assumption that companies with profits have greater motivation to announce good news faster compared to loss making companies. Contrary to the expectation, Table 7 shows that firm size has an insignificant impact on ARL. This means that regardless of the size of the company, their ARL is relatively the same. This finding may be because generally all listed companies in the UAE meet the annual reports submission deadlines of their respective markets.

Table 7: Multiple Regression Analysis

\begin{tabular}{|c|c|c|c|}
\hline Variable & Coefficients & t-value & p-value \\
\hline Constant & 79.077 & 3.212 & 0.002 \\
\hline ACS & -0.198 & -2.565 & $0.011 *$ \\
\hline $\mathrm{ACE}$ & -0.095 & -1.209 & 0.229 \\
\hline $\mathrm{ACM}$ & 0.058 & 0.696 & 0.487 \\
\hline FS & 0.013 & 0.158 & 0.875 \\
\hline PRO & -0.336 & -4.309 & $0.000 *$ \\
\hline Y2011 & 0.063 & 0.644 & 0.521 \\
\hline Y2012 & -0.031 & -0.323 & 0.747 \\
\hline MKT & 0.068 & 0.877 & 0.382 \\
\hline $\mathrm{N}$ & 149 & & \\
\hline F Value & 4.03 & & $0.000^{* *}$ \\
\hline Adjusted R Square & 0.14 & & \\
\hline R Square & 0.19 & & \\
\hline \multicolumn{4}{|c|}{$\begin{array}{l}\text { ACS }=\text { Audit Committee Size, ACE }=\text { Audit Committee Expertise, } \\
\text { ACM = Audit committee Meetings, FS=Firm Size, PRO = } \\
\text { Profitability, Y2011= }(1=\text { Year 2011, } 0=\text { Otherwise }), Y 2012=(1= \\
\text { Year 2012, } 0=\text { Otherwise })\end{array}$} \\
\hline
\end{tabular}




\section{Additional tests}

Additional analyses and robustness tests were performed to test the sensitivity of the results. Separate analyses were conducted for each sample from the different markets for 2011-2013 as shown in Tables 8 and 9. The results in Table 8 show that, based on ADX market, only profitability (PRO) has a significant impact on ARL.

Table 8: Multiple Regression for companies listed in Abu Dhabi Security Exchange (ADX)

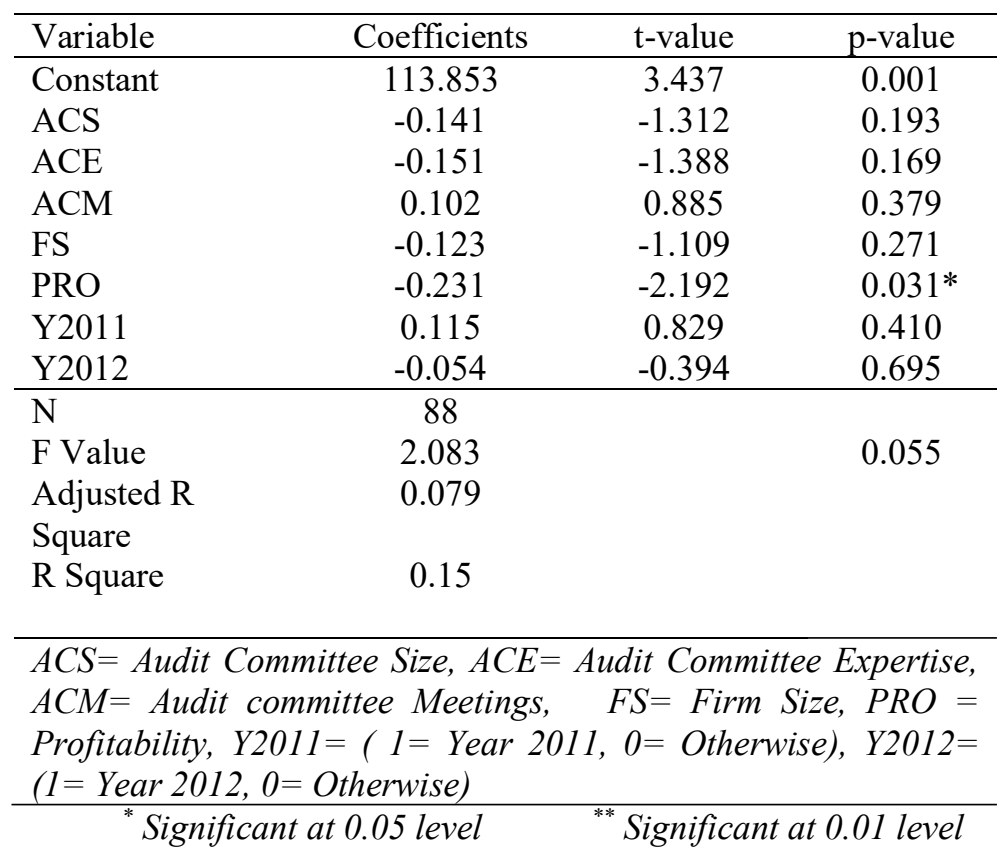

On the other hand, Table 9 shows that companies listed in DFM seemed to be consistent with the results of the pooled sample (Table 7) where audit committee size (ACS) is found to significantly impact ARL $(\mathrm{P}=0.049)$. Further analysis revealed that the variance of ACS in ADX and DFM were 0.267 and 0.328, respectively (not tabulated). McClelland and Judd (1993) stated that low variances could lead to low explanatory power, thus this could possibly explain the reason for ACS being insignificant in the ADX market but not the DFM as the latter has a higher variance than the former.

Table 9: Multiple Regression for companies listed in Dubai Financial Market (DFM)

\begin{tabular}{lccc}
\hline Variable & Coefficients & $\mathrm{t}$-value & $\mathrm{p}$-value \\
\hline Constant & 60.860 & 1.505 & 0.138 \\
ACS & -0.248 & -2.014 & $0.049^{*}$ \\
ACE & -0.018 & -0.150 & 0.881 \\
ACM & -0.011 & -0.085 & 0.933 \\
FS & 0.117 & 0.843 & 0.403 \\
PRO & -0.408 & -3.287 & $0.002^{*}$ \\
Y2011 & 0.021 & 0.135 & 0.893 \\
Y2012 & -0.022 & -0.150 & 0.882 \\
\hline N & 60 & & \\
F Value & 2.823 & & $0.014^{*}$ \\
Adjusted R & 0.18 & & \\
Square & & & \\
R Square & 0.28 & \\
\hline ACS $=$ Audit Committee Size, ACE= Audit Committee Expertize, \\
\hline
\end{tabular}




\begin{tabular}{l}
\hline ACM= Audit committee Meetings, $\quad F S=$ Firm Size, $P R O=$ \\
Profitability, Y2011= $(1=$ Year 2011, $0=$ Otherwise $), Y 2012=$ \\
$(1=$ Year 2012, $0=$ Otherwise) \\
${ }^{*}$ Significant at 0.05 level ${ }^{* *}$ Significant at 0.01 level
\end{tabular}

\section{CONCLUSION, PRACTICAL IMPLICATIONS AND FUTURE RESEARCH}

The main objective of the study is to examine the extent of ARL among listed companies in the UAE. Secondly, the study also tested the relationship between audit committee effectiveness and ARL in the UAE. The time taken (ARL) by external auditors to review company accounts is considered as the key factor that influences the timeliness of financial reports. Agency theory was applied to examine the effectiveness of an audit committee in relation to ARL. The agency theory proposes that the separation between the owner and manager subsequently leads to agency conflicts, which cause a delay in the audit process, and consequently affect the time of releasing financial reports. Thus, the audit committee mechanisms are normally an effective solution to overcome such problems and ensure the timeliness of audit work and financial reporting.

Based on the analysis of the data of the listed companies in the UAE, the results showed that auditors take an average of 60 days in meeting the requirements of either ADX and DFM, which require listed companies to publish their financial reports within 90 days and 120 days, respectively. To examine whether audit committee mechanisms influence ARL, a regression model was used to test the hypotheses. The results of regression analysis offered support only to $\mathrm{H}_{1}$, which deals with audit committee size. Furthermore, the findings revealed that only one control variable, profitability had a significant impact on ARL, which is consistent with prior studies. The remaining three control variables (company size, industry type, and auditor type (were found to have insignificant association with ARL. The results of the study indicate that the tendency of quickly releasing financial reports in the UAE is not motivated by audit committee expertise and frequency of audit committee meetings.

An audit committee, by its characteristics, is able to reduce audit business risk and improve monitoring of internal controls, which, in turn, reduces the auditor's work. Consequently, timely information can be provided, which may diminish issues of information asymmetry. The findings show that only one variable, audit committee size, has a significant influence on ARL. Thus, the study concludes that the issue of information asymmetry arising out of agency conflicts can be reduced by having a large audit committee size. On the other hand, the findings show that $\mathrm{H} 2$ and $\mathrm{H} 3$ failed to provide support for agency theory. In light of this, it is suggested that the CCG in UAE should look at the other perspectives of agency theory, such as agency problem type 2, which reflects the conflict of interest between majority and minority shareholders. UAE listed companies may face agency problem 2 because of the characteristics of the business in UAE, which are more inclined towards family businesses. Khansaheb (2008) states that family businesses constitute more than 90 percent of the economic activity in the UAE. This is supported by Madascshi (2010), who states that the appearance of agency problem 2 is more probable in countries where the ownership is concentrated in the hands of a few large shareholders and founding families.

This study is not without limitations. First, regarding the effectiveness of audit committee, the study used externally available information such as annual reports, including corporate governance reports. Future studies are suggested to use other measurements of audit committee effectiveness which require interaction with audit committee members by employing surveys or interviews. Furthermore, this study has excluded the banking sector due to the shortage of information about audit committee mechanisms in this sector. Therefore, the current findings are limited to the non-banking sector, and future research may alleviate this limitation. Additionally, the data of the period from 2011 to 2013 after the issuance of the CCG in 2009 has been used in this study. Therefore, future studies may examine the influence of audit committee effectiveness on audit delay by using data pre and post period of issuing CCG to compare the audit delay before and after that date. Another limitation is that the current study tests the effectiveness of audit committee only through audit committee size, audit committee expertise, and frequency of audit committee meetings. Hence, future studies are suggested 
to include other variables of effectiveness, such as multiple directorship and independence of audit committee, in order to provide further comprehensive insight into how effective the audit committee is in influencing ARL. Finally, the findings show insignificant impact of audit committee meetings (ACM) on ARL. Future studies are recommended to use other measures such as interviews to probe further on issues discussed and the attendance of directors during audit committee meetings which may provide meaningful findings to justify the results.

\section{REFERENCES}

Abbott, L. J., Parker, S., \& Peters, G. F. (2004). "Audit committee characteristics and restatements. Auditing: A Journal of Practice \& Theory”, 23(1), 69-87.

Abdullah, S. (2007). "Board composition, audit committee and timeliness of corporate financial reports in Malaysia". Corporate Ownership \& Control, 4(2), 33-45.

Abu Dhabi Securities Exchange (ADX). (2016). Guideline concerning listing securities on Abu Dhabi securities exchange. Available at https://www.adx.ae/DocumentCenter/adxdocs/GuidelinesConcerningListingSecuritie s-English.pdf (accessed on 1 October 2015)

Afify, H. A. E. (2009). "Determinants of audit report lag: does implementing corporate governance have any impact? Empirical evidence from Egypt". Journal of Applied Accounting Research, 10 (1), 56-86.

Al-Ajmi, J. (2008). Audit and reporting delays: "Evidence from an emerging market". Advances in Accounting, 24(2), 217-226.

Alkhatib, K., \& Marji, Q. (2012). "Audit reports timeliness: empirical evidence from Jordan". Procedia-Social and Behavioral Sciences, 62, 1342-1349.

Apadore, K., \& Noor, M. M. (2013). "Determinants of audit report lag and corporate governance in Malaysia". International Journal of Business \& Management, 8 (15), 151-163.

Balakrishnan, S, M. (2008). "Dubai-a star in the east: a case study in strategic destination branding". Journal of Place Management and Development, 1(1), 62-91.

Bamber, E. M., Bamber, L.S, \& Schoderbek, M. P. (1993). "Audit structure and other determinants of audit report lag: an empirical analysis. Auditing". A Journal of Practice and Theory, 12 (1), 1-23.

Beasley, M. S., Carcello, J. V., Hermanson, D. R., \& Lapides, P. D. (2000). "Fraudulent financial reporting: consideration of industry traits and corporate governance mechanisms". Accounting Horizons, 14 (4), 441-454.

Beasley, M. S., Carcello, J. V., Hermanson, D. R., \& Neal, T. L. (2009). "The audit committee oversight process". Contemporary Accounting Research, 26(1), 65-122.

Bedard, J., Chtourou, S. M., \& Courteau, L. (2004). "The effect of audit committee expertise, independence, and activity on aggressive earnings management". Auditing: A Journal of Practice \& Theory, 23 (2), pp. 13-35.

Behn, B.K., Searcy, D.L., \& Woodroof, J.B. (2006). "A within firm analysis of current and expected future audit lag determinants". Journal of Information Systems, 20(1), 65-86.

Carcello, J., Hollingsworth, C., Klein, A., \& Neal, T. (2006). Audit committee financial expertise, competing corporate governance mechanisms and earnings management. Working paper. Available at http://papers.ssrn.com/sol3/papers.cfm? (accessed on 23 February 2016)

Dubai Financial Market (DFM). (2016). Listing Requirements: Equity. Available at http://www.dfm.ae /issuers/listing-requirements/equity

Goh, B. (2009). Audit committees, boards of directors, and remediation of material weaknesses in internal control. Contemporary Accounting Research, 26(2), 549-579.

Fama, E. F. (1980). "Agency problems and the theory of the firm". Journal of Political Economy, 88(2), 228-307.

Jensen, M., \& Meckling, W. (1976). "Theory of the firm: managerial behavior, agency costs, and capital structure". Journal of Financial Economics, 3(4), 305-360.

Harjoto, M. A., Laksmana, I., \& Lee, R. (2015). "The impact of demographic characteristics of CEOs and directors on audit fees and audit delay". Managerial Auditing Journal, 30 (8/9), 963-997. 
Ika, S. R. (2011). The Impact of audit committee effectiveness on timeliness of reporting: Indonesian Evidence (Unpublished Master's thesis). Kulliyyah of Economics and Management Sciences, International Islamic University Malaysia.

Ika, S. R., \& Ghazali, N. A. M. (2012). "Audit committee effectiveness and timeliness of reporting: Indonesian evidence". Managerial Auditing Journal, 27(4), 403-424.

International Accounting Standards Board (IASB). (2010). The Conceptual Framework for Financial Reporting 2010. Available at https://dart.deloitte.com/resource/1/7036afd8-3f7e-11e6-95db2d5b01548a21(accessed on 21 April 2015).

Kent, P., Routledge, J., \& Stewart, J. (2010). "Innate and discretionary accruals quality and corporate governance". Accounting \& Finance, 50(1), 171-195.

Khansaheb, A. (2008). Internationalization of Family Businesses in UAE (Doctoral dissertation) British University in Dubai.

Leventis, S., Weetman, P., \& Caramanis, C. (2005). "Determinants of audit report lag: Some evidence from Athens stock exchange. International Journal of Auditing", 9(1), 45-58.

Madaschi, A. (2010). On Corporate Governance: Ownership Concentration and Firm Performance in Italy (Unpublished Master's thesis), Copenhagen Business School.

Mangena, M., \& Pike, R. (2005). "The effect of audit committee shareholding, financial expertise and size on interim financial disclosures". Accounting and Business Research, 35(4), 327-349.

Mohamad-Nor, M, N., Rohami, S., \& Wan-Hussin, W. N. (2010). "Corporate governance and audit report lag in Malaysia". Asian Academy of Management Journal of Accounting and Finance, 6(2), 57-84.

Naimi, M., Nor, M., Rohami, S., \& Wan-Hussin, W. N. (2010). "Corporate governance and audit report lag in Malaysia". Asian Academy of Management Journal of Accounting and Finance, 6(2), 57-84.

Nelson, S. P., \& Shukeri, S. N. (2011). "Corporate governance and audit report timeliness: evidence from Malaysia". Research in Accounting in Emerging Economies, 1(11), 109-127.

Owusu-Ansah, S. (2000). "Timeliness of corporate financial reporting in emerging capital markets: Empirical evidence from the Zimbabwe Stock Exchange". Accounting and Business Research, 30(3), 241-254.

Pallant, J. (2001). SPSS Survival Manual: A Step by Step Guide to Data Analysis Using SPSS for Windows (Versions 10 and 11): SPSS Student Version 11.0 for Windows. Milton Keynes, UK, USA: Open University Press.

Pucheta-Martínez, M., \& De Fuentes, C. (2007). "The impact of audit committee characteristics on the enhancement of the quality of financial reporting: an empirical study in the Spanish context". Corporate Governance: An International Review, 15(6), 1394-1412.

Saleh, N., Iskandar, T., \& Rahmat, M. (2007). Audit committee characteristics and earnings management: evidence from Malaysia. Asian Review of Accounting, 15(2), 147-163.

Sharma, V., Naiker, V., \& Lee, B. (2009). "Determinants of audit committee meeting frequency: Evidence from a voluntary governance system”. Accounting Horizons, 23(3), 245-263.

Song, J., \& Windram, B. (2004). "Benchmarking audit committee effectiveness in financial reporting". International Journal of Auditing, 8(3), 195-205.

Stewart, J., \& Munro, L. (2007). "The impact of audit committee existence and audit committee meeting frequency on the external audit: Perceptions of Australian auditors". International Journal of Auditing, 11(1), 51-69.

Xie, B., Davidson, W. N., \& DaDalt, P. J. (2003). Earnings management and corporate governance: The role of the board and the audit committee. Journal of Corporate Finance, 9(3), 295-316.

Zhang, Y., Zhou, J., \& Zhou, N. (2007). "Audit committee quality, auditor independence, and internal control weaknesses". Journal of accounting and public policy, 26(3), 300-327.

Corresponding Author: E-mail: Mohammed Ali Hussein Al-Muzaiqer can be contacted at mahalmozaiqer@yahoo.com 